\title{
The Elephant in the sale room: Ivory and the British Antiques Trade
}

\section{INTRODUCTION}

The British Antiques trade, in common with their European counter-parts, can sell worked ivory provided that they can certify that the item in question was carved before June $1947 .{ }^{1}$ Yet the ability of dealers to self-certify a piece of ivory's age in readiness for sale has led to allegations that the system is open to abuse and fraud. ${ }^{2}$ The process came under scrutiny in October 2014 when two cases came before the English Courts involving, respectively an auction house and an antiques dealer both of whom were charged with the sale of illegal ivory.

The regulation of the trade in wildlife, like the trade in cultural property, is regulated by a regime of public international law (that is, a regime of law between nations). In those states that have ratified it, the 1973 Convention on International Trade in Endangered Species of Wild Fauna and Flora ("CITES"), described as the "Magna Carta for wildlife", 3 works by controlling the import and export of certain designated species which are either at risk of extinction or could become at risk. CITES has similarities to the 1970 Convention on the Means of Prohibiting and Preventing the Illicit Import, Export and Transfer of Ownership of Cultural Property in that both were borne out of the international community's desire to protect, regulate and control vulnerable items. The UK, as a founding member of the CITES Convention joins 181 other countries in joining the Convention. Within the European Union (EU) CITES is implemented by two EU Regulations, namely Council Regulation No 338/97 which sets out the protection of CITES species by regulating trade and Commission Regulation No 865/2006 ("the Regulations") which sets out detailed rules concerning the implementation of Council Regulation No 338/97. These regulations set out the provisions regarding the issue of permits and certificates in order to create a consistent approach to the import and export of CITES species across the EU Member States. EU Regulations are directly applicable to UK law and as such no further UK legislation needs to be enacted to implement them, however the two Regulations do set out certain requirements for Member States to implement their own domestic legislation, including the penalties which will be applied for an offence. ${ }^{4}$

The UK's domestic legislation is laid down in the Control of Trade in Endangered Species (Enforcement) Regulations 1997 ("COTES"). These regulations which mirror the

\footnotetext{
1 Council Regulation (EC) No 338/97 of 9 December 1996 on the protection of species of wild fauna and flora by regulating trade, Article 8(3)

${ }^{2}$ International Fund for Animal Welfare (IFAW), Elephants on the High Street, An investigation into ivory trade in the UK, 2004.

${ }^{3}$ L. Neme, 2009, Animal Investigators

${ }^{4}$ Post "Brexit" the U.K. Parliament may consider that replacing EU Regulations already in existence not to be in the U.K.'s best interest and instead decide to implement them by way of statutory instrument. The European Union's CITES Regulations are more stringent than those laid down by the CITES Convention and so it would make sense for the U.K. to build on these rather than start again with new legislation.
} 
Regulations themselves and set out the penalties applicable for a breach of the EU Regulations. Additionally COTES also applies to any trade offences which occur with regards to CITES species within the EU. So for example a sale of a piece of post-convention ivory by an auction house or an antiques dealer would be dealt with under the COTES regulations. ${ }^{5}$ The main provision of COTES and the provision under which most prosecutions are brought is Regulation 8 which makes it an offence to purchase, offer to purchase, acquire for commercial purposes, ${ }^{6}$ display to the public for commercial purposes, use for commercial gain, sell, keep for sale, offer for sale or transport for sale any specimen ${ }^{7}$ of a species listed in Annex A to the Principal Regulation. The Regulation therefore prohibits any commercial dealing in ivory. Thus making it illegal to either buy or sell ivory or to keep ivory with the intention of selling it at a later date. Both species of modern day elephants, Elephas Maximus and Loxodonta Africana are Annex A species and as a result COTES applies to all forms of elephant ivory.

However, the Regulations also create certain derogations, one of which is directly relevant to the antiques trade. ${ }^{8}$ The Article 8 derogation, or the so-called "antiques derogation" or "worked derogation" means that it is not a breach of the Regulations to sell "worked" ivory items or items that have an ivory component, for instance furniture or musical instruments, provided the worked ivory in question pre-dates 1947. To be "worked" the item must be "significantly altered from its raw state for jewellery, adornment, art, utility, or musical instruments, and; need no further carving, crafting or manufacture 'to effect their purpose" ;9 and since May 2014 the item must be "worked across the entire surface". "Worked" specimens acquired before 1947 can be used commercially without being covered by a Commercial Use Certificate. ${ }^{10} \mathrm{~A}$ good example of a legal worked object would include an antique Japanese netsuke. These charming, charismatic miniature carvings made of wood or more commonly ivory were worn as part of the traditional Japanese dress and served the function of securing the cord at the top of the kimono sash that held the sagemono (containers that acted like a pocket to hold personal items) in place. Good examples of netsuke are exquisitely carved and reflect Japanese culture and life and can command prices of thousands of pounds today. However, it is unlawful to sell 'unworked'

\footnotetext{
${ }^{5}$ Magistrates' Court Sentencing Guidelines: Sentencing for Wildlife Trade and Conservation Offences, November 2002

${ }^{6}$ Commercial purposes does not include possessing or giving away

7 'Specimen' is defined in Article 2(t) of Council Regulation (EC) No 338/97 and includes and "animal or plant, whether alive or dead, of the species listed in Annexes A to D, any part5 or derivative thereof..."

${ }^{8}$ Council Regulation (EC) No 338/97 of 9 December 1996 on the protection of species of wild fauna and flora by regulating trade, Article $8(3)$

${ }^{9}$ Council Regulation (EC) No 338/97 of 9 December 1996 on the protection of species of wild fauna and flora by regulating trade, Article $8(3)$

${ }^{10}$ Commercial Use Certificate is also known as an Article 10 Certificate. A Certificate is required for CITES specimen listed on Annex A that are to be imported into or (re-) export from the European Union for a commercial use or for the movement of specimens within the EU where there has been a previous movement restriction imposed. Animal and Plant Health Agency, 1 January 2013. Guidance - Endangered species: imports and exports and commercial use.
} 
specimens of any date (e.g. a whole, un-carved elephant tusk). Most antiques enjoy this "antiques" exemption from the regulations. However, dealers and auctioneers need to be clear about the law when they deal in any ivory items as the timing of the working of an item is vital. For example a carved ivory bust made in 1900, having been significantly altered from its original state (a raw tusk) to make the bust 47 years before the cut-off date of June 1947, can be legally sold within the EU without the need for a CITES certificate. The bust would still come within the derogation if it had been re-carved, for example to make an ivory bead necklace, before June 1947. However, if the re-carving had been done after that date, it would be outside the derogation and need a CITES certificate from the Animal and Plant Health Agency's Licensing and Registration Service in order for it to be sold lawfully. ${ }^{11}$

In May 2013, significant changes were introduced following new guidance from the European Commission on the interpretation of the antique worked item derogation and since then the "worked item" derogation does not apply to the import or export of items outside the EU. Dealers have reported their confusion at the regulations as to the "worked item" derogation. Leading UK solicitor, Andrew Banks of law firm Stone King who advises members of the antiques trade on CITES requirements has criticised DEFRA on its "wholesale failure" to make the trade properly aware of changes to the CITES regulations. ${ }^{12}$ Banks' statement is not without foundation. The changes to the "worked item" derogation were introduced in May 2013 without prior consultation with the trade. DEFRA were criticised for publishing the changes on their website without notification to the UK trade associations. In response, DEFRA updated their website three months later admitting that the guidance they had released previously had been "confusing and in some cases misleading". ${ }^{13}$ The DEFRA licensing unit The Animal and Plant Health Agency in Bristol announced at the same time that they would publish revised guidance shortly, however, two years on, the revised guidance is still awaited.

The Regulations, while on the one hand seemingly clear and unambiguous with the 1947 cut-off date clearly stated and when an Article 10 certificate is or is not needed, have been criticised by both the members of the antiques trade and law enforcement officials. One criticism is that, on the part of the trade, there is scope for the inaccurate assessment of objects because it is not a simple feat to accurately date a piece of carved ivory. In terms of the Regulations, there is no similar provision to that say of the United States' Safe Harbor Provision of the [Convention on the] Cultural Property Implementation Act 1983 that allows items that can be proven to have been in the United States for more than twenty years to be awarded so-called safe harbour and be legal to own, sell and deal buy. ${ }^{14}$ The 1947 date is absolute and the length of time that an item has been owned is irrelevant. While experts

\footnotetext{
${ }^{11}$ Antiques Trade Gazette, 2013

12 R. Arkell, 2015, Antiques Trade Gazette

${ }^{13}$ R. Arkell, 2015, Antiques Trade Gazette

1419 U.S.C. § 2611 (2)(D) (2012).
} 
used to handling ivory artefacts may be confident in distinguishing between new ivory and ivory that was worked centuries ago (by consideration of colour and quality of carving for example) it is not so easy to make the same judgement between ivory that came from an elephant that died in the 1960s and one that died in the 1940s. While it may be true that new, untreated ivory will appear bright white, whilst antique ivory items will take on the yellow lustre of age that antique ivory collectors are looking for, the aging process can be faked and when it is faked well, without invasive carbon testing it is practically impossible to determine the true age of the item.

An analysis of the limited case law and prosecution data would suggest that the illegal sale of post-convention worked ivory in the UK falls into one of the following categories: actions by a criminal element, both organised and opportunist that operate in direct defiance of the law; ${ }^{15}$ antique dealers and auctioneers who do not have sufficiently stringent systems in place or a sufficiently high expertise to ascertain whether the items they are offering for sale are legal pre-convention ivory or illegal post-convention ivory; ${ }^{16}$ and antique dealers, auctioneers or market stall owners who may turn a blind eye to the legislation, with Portobello Road in London being singled out as a major instance of this. ${ }^{17}$

However, the reality remains that the number of reported cases involving the antiques trade and the sale of illegal ivory is very low. Between 1992 and 2014 there were 15 convictions for offences relating to the trade in ivory in the UK ${ }^{18}$ and of these 15,9 related to COTES offences (specifically with regards to Regulation 8 COTES) with the remaining being offences contrary to the Customs and Excise Management Act 1979. The antiques trade understandably points to the seeming lack of convictions and asks, with so few successful prosecutions, where is the problem? The answer to this is complex and it is suggested there are several inter-woven reasons behind both the low conviction rates and the numbers of cases being brought to court at all. In 2014 two cases came before the English Magistrates Courts involving an antiques dealer and an auction house, both charged under Article 8 (1) of the COTES. The cases, coming so closely together, were followed both by members of the antiques trade, their advisors, elephant conservation groups and prosecutors concerned with the apparent lack of cohesion in prosecution and sentencing policy for alleged breaches of the COTES regulations.

\section{THE SUCCESSFUL PROSECUTION}

\section{R v Chiswick Auctions (William Rouse) [14 October 2014, Ealing Magistrates Court]}

The first (and currently only) successful prosecution of an auctioneer in the UK for selling illegal pre-1947 ivory took place in October 2014, when Chiswick Auctions were fined

\footnotetext{
15 J. Adetunji, 2008, "Watchmaker given suspended sentence for trading ivory", The Guardian.

${ }^{16}$ R. Arkell, 2014a

17 IFAW, 2004, "Elephants on the High Street"

${ }^{18}$ From information kindly provided by the National Wildlife Crime Unit
} 
$£ 3,200$ in Ealing Magistrates Court for the sale of a carving made from ivory that came from an elephant killed during the 1960s. A general auction house with galleries in Chiswick and Twickenham, Chiswick Auction Rooms was established in 1998, and holds weekly auctions of antiques and collectables, including silver and jewellery, ceramics and works of art with each auction lotting in excess of 500 items. The auction room is familiar to the British public having regularly appeared on a number of antique and auction themed television programmes.

On $3^{\text {rd }}$ July 2012, the auction house offered for sale under lot 282 an item catalogued as "an antique carved ivory tusk worked as a train of elephants". The item had been accepted on behalf of the auction house by an experienced senior valuer, who upon inspecting it had appraised it as dating from the Edwardian era and as such falling within the Article 8 "antiques derogation".

The item sold for approximately $£ 100$ to a dealer, Mr Saeed Akhavan, a stall holder on the famous Portobello Road Market in London. During a subsequent sweep of the market by police as part of a year-long project code named "Operation Gulak", ${ }^{19}$ which saw plainclothes Special Constables, supported by officers from the National Wildlife Crime Unit, patrolling Portobello Market, checking for items being sold in contravention of The COTES Regulations, the carved tusk in question was seized and sent by police for forensic testing. The laboratory tests showed that the tusk dated from an elephant that had in fact died in the 1960s. As such, the "antiques derogation" did not apply to the carving and an Article 8(1) COTES offence had been committed. The item was tracked back to the auction house and Chiswick Auction's Managing Director, William Rouse was asked to make a statement to the police regarding the item. This was followed, sixteen months later on $19^{\text {th }}$ August 2014 , by a notice to prosecute the auction house under Regulation 8(1) COTES referring to EU Wildlife Trade Regulations Article 4 (App I).

The case was heard on the $14^{\text {th }}$ October 2014 at Ealing Magistrates Court where the auction house pleaded guilty. In mitigation, William Rouse stated that a senior auctioneer had made a genuine mistake in the age of the item. The magistrates imposed a fine of $£ 4,500$ (the maximum fine being available for the offence being $f 5,000$ ) but reduced the amount to $£ 3,200$ on account of the plea of guilty having been made by the auction house. The guilty plea brought the case to a conclusion swiftly; however, following the sentence, William Rouse told the antiques press that he believed his auction house had been the victims of "an expensive witch hunt." ${ }^{20}$ Rouse made it clear that he was shocked by the size of the fine but chose not to appeal the sentence to the Crown Court. He did however make his feeling on the judgment clear in a statement to the press which said, "a huge amount of

\footnotetext{
${ }^{19}$ Operation Gulak is led by Inspector Matthew Appleton of the Metropolitan Police Service. It is at the forefront of law enforcement efforts to tackle the trade in illegal ivory goods. The Operation is made up of a team of Special Constables working alongside the MPS Arts \& Antiques Unit.

${ }^{20}$ R. Arkell, 2014b
} 
public money has been spent on this matter but to what end? We are still permitted to sell antique ivory and what has it taught us apart from the need to be even more vigilant in a situation where every auction room in the land treads a difficult line?"21

There are several points of interest to come out of this case. This was a low value item which earned the auction house little commission. With the cost of carbon dating analysis, which is the most accurate way of dating ivory (and even then there is a margin of error of several years) well exceeding the sale price of the Chiswick lot, ${ }^{22}$ is it realistic to expect auctioneers and dealers to send low cost items for testing before sale? In addition, carbon dating involves an invasive testing procedure and although scientists are now able to date from a very small sample $e^{23}$ the fact remains that the item will be damaged to some extent. Finally, in this case, the prosecuting authorities were not prepared to rely on the "expert view" of Chiswick Auction Room's valuer who had twenty years of experience in dealing with ivory.

\section{THE UNSUCCESSFUL PROSECUTION}

\section{R v Sara Wilkinson [20.10.2014 Isleworth Crown Court]}

Sara Wilkinson's business, Chanticleer Antiques, specialises in small antiques and collectables, including ivory carvings and portrait miniatures on Portobello Road in London. In April 2014, Wilkinson was charged with the sale of an ivory carving of a nude figure that police believed to have been worked after June 1947. The case was widely publicised in the national and trade press ${ }^{24}$ and unlike the Chiswick case, Wilkinson's ivory figure was not sent for forensic testing as part of the prosecution case. Wilkinson, a dealer with more than 47 years of experience of dealing in ivory, was approached on August 12, 2013, in the Dolphin Arcade by police officers from the Metropolitan Police Service and asked about three items in her stock: a small carved tusk (that Wilkinson correctly assessed not to be made of elephant ivory), a taxidermy terrapin and an ivory carving of a nude and a cherub which Wilkinson had appraised as dating from c.1870, which she was offering for sale at £3250.

On November 9, of the same year Wilkinson was asked to attend Notting Hill police station for interview. At that time, two of the items that had been seized by police on the $12^{\text {th }}$ of August (the terrapin and the carved hippo tusk) were returned to her, the police being satisfied that neither were from species listed as Appendix A by CITES and both were old 'worked' items. However, the carved ivory figure was retained by police and Ms Wilkinson was asked to prove both the age of the carving and its source. Referring to her business records, Ms Wilkinson was able to give the police details as to how and when the

\footnotetext{
${ }^{21}$ R. Arkell, 2014c

22 Oxford University, Oxford Radiocarbon Accelerator Unit, 2015

${ }^{23} \mathrm{lbid}$.

${ }^{24}$ Antiques Trade Gazette, 2014c
} 
figure had been acquired by her. However, she was not able to provide evidence as to the age of the carving beyond her belief, as a dealer with more than 40 years of experience in handling ivory, that it dated to the second half of the 19th century based on the quality and style of the carving. On April 24 2014, the dealer was informed that she would be charged with the sale of a modern elephant ivory carving contrary to Article 8 of the Control of Trade in Endangered Species (Enforcement) (COTES) Regulations 1997 because she had failed to produce written documentation confirming the age of the carving. The case rested on how the age of the item should be proven. Whereas the Chiswick case was proven on the basis of forensic testing carried out by the prosecution, the ivory in the Chanticleer case was not dated by the prosecution nor was it sent for forensic testing at any time during the case, rather the police prosecution team, led by Inspector Matthew Appleton of the Metropolitan Police Service, proceeded on the basis that the burden of proof in respect of the age of the carving being shown to preceded the 1947 date lay with the Defendant. "In other words," Ms Wilkinson told reporters, "I was guilty until I could prove my innocence."25

Wilkinson was in fact one of several stand holders that were questioned by a unit of Special Constables, again as part of Scotland Yard's "Operation Gulak". However, where her colleagues on the Portobello Road chose to take a police caution, Wilkinson stood by her assertion that the carving in question was legal pre-1947 worked ivory and after entering a plea of "not guilty" at the Hammersmith Magistrates Court on the $22^{\text {nd }}$ January 2015, the case was sent to Isleworth Crown Court for hearing but the day before the final hearing the Crown Prosecution Service (CPS) announced that it would no longer be offering any evidence in the case on the grounds that there was not a realistic prospect of conviction. It is suggested that there had been a dispute between the CPS and the police officers involved on how to proceed in the prosecution of the case, including difficulties encountered in finding an expert witness willing to rule on the date of the carving and the failure to submit the carving for carbon dating. ${ }^{26} \mathrm{Ms}$ Wilkinson attended court merely to be formally found not guilty with the judge describing placing the burden of proof on the defendant as "a bridge too far". ${ }^{27}$ However, without a binding judicial determination (the judge's comments in Wilkinson are obiter, meaning the judge's words are not binding as future precedent) the enforcement authorities assertion that the burden of proof in determining the age of an ivory object should lie with the Defendant remains untested.

\section{ANALYSIS}

The difference in the prosecutors' approach in these two cases invites questions as to how future prosecutions will be conducted. The presumption of innocence is a corner stone of English $\operatorname{law}^{28}$ and the prosecuting authorities attempt to reverse this should

\footnotetext{
${ }^{25}$ Antiques Trade Gazette, 2014c

${ }^{26}$ Antiques Trade Gazette, 2014c

${ }^{27}$ Antiques Trade Gazette, 2014c

${ }^{28}$ Human Rights Act 1998, Sch 1, Art. 6(2)
} 
concern the antiques trade. In addition, consideration should also be given as to the binding effect of the Crown Court upon itself and the Magistrates Court, from which it hears appeals. The Crown Court derives its jurisdiction from the Senior Courts Act $^{29}$ which provides that the "Crown Court shall be a senior court of record" 30 which suggests that decision of the Crown Court will be binding. However, there is a difference between the binding nature of Crown Court decisions made on indictment (in which an appeal against conviction or sentence will be heard by the Court of Appeal, Criminal Division) and those decisions that are made on a point of law, which are not binding, although they are of persuasive authority. The police and CPS have stated that in their view, future prosecutions will be brought on the basis that it is for the Defence to prove the age of the artefact in question. In a CPS Memorandum of Understanding prepared following the collapse of the Wilkinson case, it is concluded that "notwithstanding situations where a specimen's identity is obvious, the law provides that if a specimen is advertised, displayed or otherwise packaged as being/containing a controlled specimen, it shall be taken as such and the Crown is under no obligation, legal or otherwise, to prove its nature." ${ }^{31}$ However, following Wilkinson nothing has changed. Dealers still have the benefit of the Article 8 "antiques derogation" and without a binding judgment to the contrary or a decision by the prosecution to bear the cost of forensic testing in every case, self-certification of the age of an item by a dealer remains.

When considering the COTES legislation it is impossible to ignore its European heritage coming as it does out of European Council Regulations (EC) No 338/97 and (EC) No $865 / 2006$ and as such considering a decision from the courts of another European country make an interesting comparison when it comes to how the prosecution makes their case and where the burden of proof lies.

In September 2013, one of Sweden's best regarded and well-established auction houses was investigated for trading illegal ivory. The Uppsala Auktionskammare, which specialises in fine arts and antiques, were investigated for placing thirty ivory items for sale on their online auction site. The ivory was seized by Swedish police who suspected it to have come direct from poachers. The auction house was charged by the Swedish Prosecutor with "intentionally or negligently in the course of business at its online auction on August 27, 2013 selling or holding for sale, fifteen items of illegal processed elephant ivory" without the required "CITES certificates or documentation showing that the items are exempt from the provisions of Article 8.1 and 8.5 of Council Regulation (EC) No 338/97 of 9 December 1996 on the protection of species of wild fauna and flora by regulating trade therein". The case pivoted on how the auction house proved the ivory items being sold were pre-1947 and therefore legal ivory objects with the antiques exemption. The Prosecution relied upon the

\footnotetext{
${ }^{29}$ Sections 45-48 Senior Courts Act 1981

${ }^{30}$ Section 45(1) Senior Courts Act 1981

${ }^{31}$ A. Caird, Senior Crown Prosecutor, Memorandum of Understanding $11^{\text {th }}$ May 2015.
} 
fact that Uppsala Auktionskammare offered the items for sale without scientific testing, having instead relied on the expert advice of their senior valuer, Charlotte Widenfelts. The Court, in its judgement found that: "...there is nothing in the evidence which the prosecution has relied on that in any way contradicts the data in Charlotte Widenfelt's testimony about the objects' age" so that "the auction House has thus, by examination of the witness Charlotte Widenfelt, substantiated its claim that all of the items covered by the application were worked before 3 March 1947". The court concluded that the items were therefore exempt from the CITES regulations. In his summary the District Judge placed great emphasis on the expertise of the valuer, Charlotte Widenfelt, who had been asked to give a second evaluation of the items being offered for sale. As an Oriental Art specialist and a nationally accepted authority on antique ivory (she is an expert on the Swedish "Antiques Roadshow" programme), he accepted her testimony that, based on her knowledge and experience, the items were legal. The items themselves were never, either before or during the court case, subjected to scientific testing. The distinction between this case and those in the UK is notable because the UK and Sweden have exactly the same rules regarding the sale of CITES regulated items but clearly the prosecuting authorities are now viewing the means to prosecution in very different ways.

Following the Wilkinson case, the successful prosecution of COTES offences involving ivory are arguably at something of an impasse. The CPS's Memorandum of Understanding may show a determination to successfully prosecute the sale of illegal ivory but the CPS has been criticised in respect of their handling of COTES prosecutions. In 2006, the National Audit Office (NAO) identified a host of poor administrative practices by the Crown Prosecution Service (CPS) in their handling of prosecutions of wildlife crimes highlighting a lack of specialist knowledge on the part of the CPS. The NAO highlighted issues which included the poor preparation of cases leading to delays, poor case tracking with files going missing and inadequate prioritisation of cases. There is evidence, as seen in the Wilkinson case, that this leads to an understandable conflict between investigators, who may have spent many months or years gathering evidence to bring a case to court seeing their cases collapse through what they perceive as the incompetence of prosecutors. However, in accordance with guidelines set down and published by the CPS, wildlife crimes need to have a better than $51 \%$ chance of successful prosecution and be in the "public benefit" to warrant being brought to court. Regrettably, previously conducted criminological research ${ }^{32}$ has shown that cases involving wildlife crime have continually failed to meet the second of these criteria, either because of the perceived effect of the crime on the species in question (the argument, perhaps that prosecuting a dealer for selling ivory from an elephant that died in the 1960s will have no detrimental effect on the current elephant population) or because the crime is seen as being low priority in terms of the value of the item. With ivory

\footnotetext{
${ }^{32}$ A. Nurse, 2012, Internet Journal of Criminology
} 
items changing hands at car boot sales, auctions and fairs for tens of pounds this is perhaps understandable, at least in terms of the economics involved.

\section{CONCLUSION}

The British government is on the verge of making changes to the COTES regulations and considering imposing a blanket ban on the sale of all ivory, be it antique or not and this is understandably of concern to the antiques trade who fear not only for their businesses but also for the potential loss of important cultural and artistic pieces. The view of dealers and auctioneers who have already seen a negative impact on their sales in ivory following the US ban was eloquently expressed by Rebecca Davies, Chief Executive of LAPADA when she said that the implementation of the manifesto promise would be "the final nail in the coffin for many of them whose expertise is focused on items that historically contain ivory." ${ }^{33}$ In view of the potential economic loss to the antiques industry, the British Government together with its CITES partners, whilst being understandably concerned about the rise in the illegal ivory trade, require a unified, coordinated policy with regards to the prosecution of Article 8 offences. Following the collapse of the Wilkinson case, clarification is needed both for the trade and their advisors and the prosecuting authorities however there are a number of reasons as to why such clarification may be slow in coming.

Firstly, the Crown Prosecution Service and the Metropolitan Police Service may, as evidenced in their stance in the Wilkinson case and the Crown Prosecution Service's memorandum that followed it, want to see the burden of proof placing the requirement to prove the age of an ivory item (and by this they mean forensic testing) on the Defendant rather than the Crown but the only judge to consider it has deemed this approach to be "a bridge too far". Inspector Matthew Appleton, as the officer leading the MPS investigations regarding the antiques trades' sale of items derived from CITES species has been clear in his assertions however, that with no ratio (that is the point in a case that determines the judgment) or obiter (a judge's expression of opinion but not essential to the decision and therefore not legally binding as a precedent) to support (in fact no common law support at all) the burden should lie with the seller in proving the age of an item. In other words, Inspector Appleton wishes to see COTES offences involving ivory prosecuted on a strict liability basis unless the supporting provenance shows otherwise. Strict liability offences are those which require no proof of mens rea (the intention or knowledge of committing the offence) in relation to one or more aspects of the actus reus (the action or conduct of the accused in committing the offence). Strict liability offences are primarily regulatory offences aimed at businesses in relation to health and safety but also include many driving offences including speeding and driving without insurance. The use of strict liability in criminal law is controversial as it means a person may be liable where they are not at fault or have taken all

\footnotetext{
33 I. Macquisten, 2015, The Antiques Trade Gazette
} 
reasonable care to ensure compliance of the law as was seen in Callow v Tillstone. ${ }^{34}$ This approach would bring an end to the ability of a dealer or auction house to simply rely on their expertise and knowledge. This stance points to a showdown between prosecutors and the courts and until a case similar to Wilkinson is heard in full or the COTES legislation is changed, the trades' understanding of the law and in particular the burden of proof, and that of the police and CPS will remains in contention. Secondly, current forensic testing, which could prove to be the solution, is expensive and invasive. Until science has created a cheap, non-invasive and accurate test dealers will be wary. Carbon dating was used in the Chiswick case to determine that the elephant from which the carved tusk had come had died in the 1960s. Carbon dating uses a method which measures the activity of the radioisotope carbon-14 still present in the tested sample. In terms of the types of ivory items being sold, this type of testing has two major drawbacks. The first of these is that Carbon 14 testing works by measuring the level of carbon and during the lifetime of any organism, human, plant or elephant it is continually taking in carbon from the atmosphere around it. When the organism dies, it stops taking in new carbon. In terms of elephant ivory, the test can be used to determine whether or not the animal died before or after the crucial 1947 date. During the early part of the 1950's atmospheric nuclear weapons testing had the effect of artificially increasing the amounts of different isotopes of the element carbon, particularly carbon 14 to the extent that it had double in readings by 1965 . As such, scientists can show whether or not a piece of ivory pre-dates this period by showing that it has a lower ratio of $14 \mathrm{C}$ than more modern ivory will. However, there have been questions of the accuracy of carbon 14 testing with assertions such as "... fewer than 50 percent of the radiocarbon dates from geological and archaeological samples in north-eastern North America have been adopted as 'acceptable' by investigators." 35 Forensic testing is also expensive. Currently a schedule of fees from a leading British laboratory as to the cost of radioisotope analysis for the test of a single article show their fees to be $£ 450$ plus VAT. ${ }^{36}$ Bearing in mind that the carved tusk in the Chiswick case sold for $£ 100$ forensic testing is simply not economically viable for items such as this. Finally, current forensic testing methods are invasive and involve taking a sample from the object to subject to analysis. Whilst the amount required is small, the resulting damage will be proportionate. Even a tiny sample from a delicate portrait miniature will be catastrophic. If prosecutors want to see COTES breaches become strict liability offences, the question of reliable, affordable and non-destructive forensic testing must be addressed.

Finally, what of the legislation and the law makers themselves? Whilst the E.U. Regulations control the trade in CITES species, they give the Member States jurisdiction as

\footnotetext{
${ }^{34}$ Callow v Tillstone (1900) 64 JP 823 322, saw a butcher convicted of selling unfit meat despite the fact that he had had the meat certified as safe by a vet before the sale. His conviction was upheld as the offence was one of strict liability and it mattered not how diligent he had been to ensure the safety of the meat.

35 J. Ogden, III, 1977, Annals of the New York Academy of Science

${ }^{36}$ Oxford University, Oxford Radiocarbon Accelerator Unit, 2015
} 
to penalties for breaches and as the differences between the prosecution of Uppsala Auktionskammare and that of Wilkinson demonstrates this can result in contrary decisions across the E.U. This is an issue because dealers and auction houses in the U.K. have a welldeveloped and important cross-Channel trade with their mainland European colleagues and see them subjected to seemingly different rules to them. Meanwhile, the trade have expressed their confusion at the U.K. legal position and at the lack of guidance from DEFRA. The department, to whom many of the antiques trade turn for guidance in respect of CITES rules, failed to advertise the changes to the worked specimen rules made in 2013. By their own admission in a press release posted on the DEFRA website on the $20^{\text {th }}$ August 2013 , the admitted that information was "confusing and in some cases misleading".

In terms of British Government policy, the U.K. antique trader have, by previous governments been given assurances that with regard to pre-1947 worked items, the Government would not seek to put an end to trade in antique ivory. ${ }^{37}$ However, the Conservative Party's Manifesto re-iterated its intention to press for a total ban on the sale of ivory and this time, the previous assurances to the trade were lacking. As a result, it is not clear where the antiques trade stands in the British Government's stance on the sale of ivory. What is clear, is that there are conservation groups lobbying the Government to make good on its pledges to push for a ban on the sale of all ivory (particularly in light of President Obama and President Xi Jinping of China joint announcement to end ivory sales in China ${ }^{38}$ ) and this is an understandable concern to the antiques trade.

The British Antiques Dealers Association estimate that there are more than two million items made either entirely of ivory or with an ivory component in ordinary homes across the United Kingdom from pianos with ivory keys, to puzzle balls, portrait miniatures and billiards balls. It is likely that at some point their current owners will wish to sell them and will seek advice from UK auction houses and dealers. As the law stands it is still legal to sell pre-1947 worked ivory items and until a case comes to court which says differently it remains for the seller to assert the age of the piece in question and for the prosecution to prove otherwise. However, the Wilkinson case and the stance of the MPS led by Inspector Appleton has resulted in a palpable concern about selling ivory amongst the UK's antiques dealers and auction houses to the extent that some, following Chiswick Auction Room's lead, are now refusing to sell any at all. ${ }^{39}$

Clarity and clear direction is urgently needed, not just for the antiques trade but also for the many owners of ivory items, either inherited or collected, who may wish to sell at some time in the future. For some this may simply be a small memento of little value passed down through their family but for others, such as a retired solicitor who recently contacted the writer, it could represent a collection of culturally significant and valuable ivory artefacts

\footnotetext{
${ }^{37}$ Ivan Macquisten, Antiques Trade Gazette, 2015

${ }^{38}$ The White House, Office of the Press Secretary, 25 September 2015

${ }^{39}$ R. Arkell, 2014d
} 
that forms the basis of their pension policy and significant percentage of the value of their estate. To see this reduced to nothing will be personally devastating.

\section{BIBLIOGRAPHY}

Adetunji, J. 2008, "Watchmaker given suspended sentence for trading ivory", The Guardian. Available at: http://www.theguardian.com/uk/2008/jun/14/ukcrime.conservation (accessed Dec. 02, 2015)

Antiques Trade Gazette, 2013, "CITES Guide”, Antiques Trade Gazette. Available at: https://www.antiquestradegazette.com/guides/information-guides/endangered-species/ (accessed Aug 24, 2015)

- 2014e, "Asking Portobello dealer to prove age of ivory carving is 'a bridge too far' says judge", Antiques Trade Gazette. Available at:

http://www.antiquestradegazette.com/news/2014/nov/25/asking-portobello-dealer-toprove-age-of-ivory-carving-is-a-bridge-too-far-says-judge/ (accessed Dec 15, 2015)

— . 2014f, "Asking Portobello dealer to prove age of ivory carving is 'a bridge too far' says judge", Antiques Trade Gazette. Available at:

http://www.antiquestradegazette.com/news/2014/nov/25/asking-portobello-dealer-toprove-age-of-ivory-carving-is-a-bridge-too-far-says-judge/ (accessed Dec 15, 2015)

— . 2014g, "Asking Portobello dealer to prove age of ivory carving is 'a bridge too far' says judge", Antiques Trade Gazette. Available at:

http://www.antiquestradegazette.com/news/2014/nov/25/asking-portobello-dealer-toprove-age-of-ivory-carving-is-a-bridge-too-far-says-judge/(accessed Dec 15, 2015)

Arkell, R. 2014a, "Auction house fined $£ 3200$ over ivory breach", Antiques Trade Gazette. Available at: http://www.antiquestradegazette.com/news/2014/oct/20/auction-housefined-3200-over-ivory-breach/ (accessed Sept 20, 2015) —. 2014b, "Auction house fined $\mathbf{} 3200$ over ivory breach", Antiques Trade Gazette. Available at: http://www.antiquestradegazette.com/news/2014/oct/20/auction-housefined-3200-over-ivory-breach/(accessed Sept 20, 2015) —. 2014c, "Auction house fined $£ 3200$ over ivory breach", Antiques Trade Gazette. Available at: http://www.antiquestradegazette.com/news/2014/oct/20/auction-housefined-3200-over-ivory-breach/ (accessed Sept 20, 2015) —. 2014d, "Auction house fined $£ 3200$ over ivory breach", Antiques Trade Gazette. Available at: http://www.antiquestradegazette.com/news/2014/oct/20/auction-housefined-3200-over-ivory-breach/ (accessed Sept 20, 2015) 
—. 2015, "Lawyer slams DEFRA over CITES chaos", Antiques Trade Gazette. Available at: http://www.antiquestradegazette.com/news/2015/lawyer-slams-defra-over-cites-chaos (accessed July 1st, 2015) International Fund for Animal Welfare (IFAW), 2004, "Elephants on the High Street: An investigation into ivory trade in the UK". Available at:

http://www.ifaw.org/sites/default/files/Elephants\%20on\%20the\%20high\%20street\%20an\% 20investigation\%20into\%20ivory\%20trade\%20in\%20the\%20UK\%20-\%202004.pdf (accessed Aug 15, 2015)

Macquisten, I. 2015, "UK ivory ban would destroy my business", Antiques Trade Gazette. Available at: https://www.antiquestradegazette.com/news/2015/uk-ivory-ban-woulddestroy-my-business/(accessed May $5^{\text {th }}, 2015$ )

Neme, L . 2009, “Animal Investigators”, New York, Scribner Publishers

Nurse, A. 2012, "Repainting the Thin Green Line: The Enforcement of UK Wildlife Law", Internet Journal of Criminology. Available at:

http://www.internetjournalofcriminology.com/Nurse Repainting The Thin Green Line IJ C Oct 2012.pdf (accessed Feb 22, 2016)

Ogden, J. III, 1977, "The Use and Abuse of Radiocarbon," in Annals of the New York Academy of Science, Vol. 288, 1977, pp. 167-173.

Oxford University, 2015, Oxford Radiocarbon Accelerator Unit: "Radiocarbon Dating for Art History", Oxford University. Available at:

https://c14.arch.ox.ac.uk/embed.php?File=leaf art.html (accessed Nov 10, 2015) - . 2015, Oxford Radiocarbon Accelerator Unit: "Schedule of charges", Oxford University. Available at: https://c14.arch.ox.ac.uk/embed.php?File=charges.php (accessed Feb 15, 2016)

Press Association, 2014, "Prince William calls for Buckingham Palace ivory to be destroyed",

The Guardian. Available at: http://www.theguardian.com/uk-news/2014/feb/17/princewilliam-buckingham-palace-ivory-destroyed (accessed Nov 10, 2015)

The Conservative Party Manifesto, 2015, P. 55. Available at: https://www.conservatives.com/manifesto (accessed Dec 4, 2015) 
The U.S. Fish and Wildlife Service, 2014, "DIRECTORS ORDER NO.210", The U.S. Fish and Wildlife Service. Available at: http://www.fws.gov/policy/do210.html (accessed Jan 18, 2016) 